\title{
What Good Is a College Degree? Education and Leader Quality Reconsidered
}

\author{
Nicholas Carnes, Duke University \\ Noam Lupu, University of Wisconsin-Madison
}

Do people with more formal education make better political leaders? In this article we analyze cross-national data on random leadership transitions, data on close elections in the US Congress, and data on randomly audited municipalities in Brazil. Across a wide range of outcomes, we consistently find that college-educated leaders perform about the same as or worse than leaders with less formal education. Politicians with college degrees do not tend to govern over more prosperous nations, do not pass more bills, do not tend to do better at the polls, and are no less likely to be corrupt. These findings have important implications for how citizens evaluate candidates, how scholars measure leader quality, and how we think about the role of education in policy making.

\begin{abstract}
Laws will be wisely formed and honestly administered in proportion as those who form and administer them are wise and honest; whence it becomes expedient for promoting the public happiness that those persons whom nature has endowed with genius and virtue should be rendered by liberal education worthy to receive and able to guard the sacred deposit of the rights and liberties of their fellow citizens.

— Thomas Jefferson, Diffusion of Knowledge Bill, 1779
\end{abstract}

[Although] education is universally a key credential for elite recruitment ... studies of elite socialization have found little or no consistent impact of the quantity of education a leader has received.

—Robert Putnam, The Comparative Study of Political Elites, 1976

$\mathrm{D}$ o people with more formal education make better politicians? The idea has deep roots in both classical and contemporary political thought. Since Plato, political observers have often argued that governing is best left to those who are highly educated (e.g., Lippmann 1922). Ordinary citizens have often agreed. In 2009, a New York Times education blog reported that $5 \%$ of members of Congress did not have college degrees (Steinberg 2009), prompting a flurry of readers to comment, "I would never vote for anyone who did not have a college degree"; "It's foolish to think that an uneducated ... legislature would be preferable to an educated one"; and "I don't think some one [sic] who didn't graduate from college is qualified to run the country."

Many social scientists have recently started to agree. In recent years, many scholars have begun using information about the formal educational attainment of political leaders as a rough measure of the quality or competence of those leaders. The practice has spread quickly: in the span of a few years, statements like "we use education as a proxy for the skill level of candidates" (Kotakorpi and Poutvaara 2011,879 ) have become commonplace in research on topics ranging from political selection (Bai and Zhou 2014; Besley and Reynal-Querol 2011; Buckley et al. 2014; Galasso and Nannicini 2011; Luo 2010) and gender quotas (Baltrunaite et al. 2012) to legislative compensation (Atkinson and Rogers 2012; Kotakorpi and Poutvaara 2011), leader survival (Yu and Jong-A-Pin 2013), and voter turnout (De Benedetto and De Paola 2014). Scholars now routinely assume that educated leaders tend to be better leaders.

However, they usually present little evidence to support that assumption. When scholars use education as a proxy for leader quality, they sometimes cite research on ordinary citizens showing that education is a marker of human capital or civic skills. Most also point to a recent article linking the educational attainment of political leaders to gross domestic product (GDP) growth (Besley, Montalvo, and Reynal-

Nicholas Carnes (nicholas.carnes@duke.edu) is assistant professor of public policy at the Sanford School of Public Policy at Duke University, Durham, NC 27708. Noam Lupu (lupu@wisc.edu) is assistant professor of political science and Trice Faculty Scholar at the University of Wisconsin-Madison, Madison, WI 53706.

Data and supporting materials necessary to reproduce the numerical results in the article are available in the JOP Dataverse (https://ataverse .harvard.edu/dataverse/jop). An online appendix with supplementary material is available at http://dx.doi.org/10.1086/683027. 
Querol 2011). But most do little more: there simply is not much empirical research on the link between politicians' educational attainment and their performance in office.

That link deserves more careful attention. The relationship between education, competence, and leadership is more complex than many scholars have assumed-and the existing empirical evidence is more mixed than they have acknowledged. Teachers who earn master's degrees do not appear to produce better students (e.g., Clotfelter, Ladd, and Vigdor 2007). Chief executive officers (CEOs) with more schooling do not seem to produce higher profits (e.g., Gottesman and Morey 2006). Perhaps politicians with more formal education do not produce better government.

In this article we ask whether leaders with college degrees perform better in office than leaders without college degrees. Whereas past studies have focused on just one measure of a leader's performance-how much the economy grows while the leader is in office-we focus on a wide range of outcomes: economic growth, inequality, social unrest, interstate conflict, unemployment, inflation, reelection, legislative productivity, and corruption.

Of course, it is possible that educated people might be more likely to seek political office in places where outcomes like these are already good. To deal with this potential selection bias, we follow previous work and analyze crossnational data on leaders who take office unexpectedly (because the previous leader suddenly became ill or died). To extend the empirical evidence, we also analyze two data sets that allow for easy single-country extensions of the findings in this larger data set: data on members of the US Congress and Brazilian mayors who were first elected essentially at random (by winning an extremely close election). In these three data sets, does it matter whether a politician has a college degree or not?

In sharp contrast to the assumptions underpinning recent studies, we find little evidence of a link between education and leader quality: on the measures we examine, collegeeducated politicians perform about the same as or worse than leaders who do not have college degrees. Politicians with college degrees do not tend to govern over more prosperous nations, are not more productive legislators, do not perform better at the polls, and are no less likely to be corrupt. These findings have important implications for how citizens evaluate candidates, how scholars measure leader quality, and how we think about the role of education in policy making.

\section{EDUCATION AND LEADER QUALITY}

Why would we expect politicians who have more formal education to be better leaders? The most common answer in the scholarly literature is that people with more school- ing have more human capital and tend to be more engaged in civic life. In their work on whether democracies select more educated leaders, Besley and Reynal-Querol $(2011,552)$ argue that

education is a particularly interesting aspect of political selection in view of the strong correlation found between educational attainment and earnings, which is consistent with education either enhancing skills or signaling ability. Education is also strongly correlated with civic engagement. Education is thus a compelling indicator of a leader's quality.

Similarly, Atkinson and Rogers $(2012,6)$ note that

scores of papers have established a clear link between education and lifetime income, and education is a clear contributor to civic engagement, from the simple act of voting to dedicated activism. In the political realm, those with higher education have a distinct advantage in being better able to develop logical arguments, assemble and assess evidence, and make public presentations ... university degrees signal capacity in this regard and invite the inference that education provides at least some politically relevant skills.

De Benedetto and De Paolo $(2014,6)$ note too that it is impossible to directly measure a leader's competence or ability in some abstract sense:

Since it is not possible to find one or more indicators that unquestionably determine what makes a good politician, we measure politicians' quality in terms of human capital. There is a huge economic literature showing that a higher accumulation of human capital produces positive effects both on individual economic prospects and on aggregate variables. Under the assumption that "political" and "market" skills are correlated, human capital should also represent a good proxy for politicians' quality.

Why use education to measure leader quality? Because people with more education tend to have more of the skills that make employees valuable and that make it easy for citizens to engage in politics. If those skills are also helpful while running a campaign or holding a political office, people with more education will tend to be better politicians.

But are they? The empirical evidence is murkier than recent studies acknowledge. The link between education and human capital, for instance, is not as straightforward as 
they suggest. People with more formal education do, in fact, earn more money, perhaps because schooling imparts valuable skills or perhaps because people seek out schooling to signal that they have valuable skills (e.g., Card 1997). Likewise, people with more education are considerably more likely to be involved in civic life, perhaps because education encourages engagement or perhaps because people who are engaged also tend to seek out schooling (e.g., Verba, Schlozman, and Brady 1995).

However, there are also signs that the links between education and human capital or civic engagement are not wholly attributable to learning or signaling. Some of the differences between people with more and less education may instead reflect social and economic exclusion (see Massey 2007). The costs associated with education keep some talented people from pursuing degrees (and enable some less talented people with economic resources to pull ahead). In turn, education confers lifelong economic and social benefits. People with degrees may earn more not because they have superior skills but because employers assume that degrees are markers of quality and offer more pay to people who have them. ${ }^{1}$ People with more education may also participate in civic life more not because they have superior abilities, but because the political process tends to be more responsive to more privileged people and they have more to gain by engaging (e.g., Bartels 2008; Gilens 2012). The links between education and earnings or civic engagement undoubtedly reflect differences in skills and abilities-but education signifies more than just human capital, including preexisting privileges that have nothing to do with a person's competence. The relationship between education and human capital is not as straightforward as recent studies of leader quality suggest.

The link between human capital and leader quality is also less certain. Education can impart many skills that may be useful in politics. But most formal education does not directly focus on how to run for or hold political office. Campaigning and governing are highly specialized tasks, and the human capital people acquire from formal education may not give them big advantages when they decide to seek public office. Moreover, because holding office requires so much human capital in the first place, people with less formal education (and, for that matter, people with more) who make it to leadership positions may have far more human capital than the average person from their education level. Even if there is an association between education and ability in the gen-

1. The study that found that CEOs with more schooling do not generate more profits also found that $\mathrm{CEO}$ with more schooling receive higher compensation (Gottesman and Morey 2006). eral public, if the processes we use to select leaders screen out people with less human capital, the association between education and human capital among politicians may be weakor nonexistent.

Scholars are beginning to reach the same conclusions about the links between educational attainment and performance in other skilled professions. Using longitudinal data on individual student achievement, Clotfelter et al. (2007) show that teachers who earn master's degrees do not produce greater learning gains for students (either before or after receiving their advanced degrees). Likewise, using data on the CEOs of companies traded on the New York Stock Exchange, Gottesman and Morey (2006) show that companies do not make greater profits when they are led by CEOs educated at more selective colleges or CEOs with law degrees or MBAs. This may be because the selection process for complex professions screens out all but the most qualified people, so that all teachers and CEOs are higher in human capital regardless of their education levels. Or it may be because formal education is a marker of general skills and abilities, but those skills are not enough to ensure that someone can run a classroom or a company or a country (e.g., Carnevale, Inbar, and Lerner 2011). Even if ordinary citizens with more formal education have more human capital, there are good reasons to doubt that leaders with more education are all that different from leaders with less.

Indeed, the relationship between education and leader quality-the assumption underpinning dozens of recent studies-is far more empirically tenuous than those studies let on. Most studies that treat education as a marker of leader quality cite just one empirical study by Besley et al. (2011) that analyzes cross-national data on random leadership transitions between 1875 and 2004. When a collegeeducated leader dies of natural causes, the study shows, GDP per capita decreases more if the incoming leader has less formal education. ${ }^{2}$ When scholars "use education as a proxy for the skill level of candidates" (Kotakorpi and Poutvaara 2011, 879), most cite this study alone.

This study-and two others cited less often ${ }^{3}$-is not enough to justify the widespread assumption that politicians

2. Curiously, the study also finds that GDP per capita declines when the transition transfers power from one college-educated leader to another college-educated leader and increases when it transfers power from a leader with no college degree to another leader with no college degree.

3. A more comprehensive review of the literature uncovers two more studies, though even this expanded body of evidence is far from bulletproof. Congleton (2013) finds that GDP growth in the United States is higher when the president has more formal education, but the study does not control for other factors that might influence both GDP growth and the educational backgrounds of presidents, including the rapid increase in 
with more education are better politicians. GDP growth is not a universal measure of a leader's performance or of a nation's prosperity: countries can experience positive GDP growth during periods of soaring economic inequality, social unrest, interstate conflict, and widespread corruption. Moreover, it is difficult to know how much credit political leaders deserve for changes in economic output. And if education is a proxy for things like social class, ideology, or party affiliation, the association between education and GDP may reflect something other than a difference between more and less skilled leaders. A single study linking educated leaders to increasing GDP is certainly consistent with the idea that educated leaders are better, but it is by no means definitive.

Nor is it the only word on the matter: most of the scholars who equate education and leader quality have ignored an earlier body of research suggesting that leaders with more formal education tend to think and behave about the same as leaders with less formal education. In the 1960s, scholarship on the personal backgrounds of political elites briefly flourished (e.g., Domhoff 1967; Gruber 1971; Lipset and Solari 1967; Verner 1974; Von der Mehden 1969). Many of these studies analyzed the relationship between leaders' educational backgrounds and their attitudes, choices, and decisions in office. Most came up empty-handed, finding "little or no consistent impact of the quantity of education a leader has received" (Putnam 1976, 94). Since then, followup studies have likewise found essentially no differences between how more and less educated politicians behave in office (e.g., Carnes 2012, 2013). ${ }^{4}$ If more educated leaders tend to behave about the same as other politicians, why should we assume that they produce significantly better outcomes?

It is possible that more educated leaders differ in some way that these behavioral studies simply did not pick up. We may reach different conclusions if we focus not on politicians' behaviors but rather on economic and social outcomes. As it stands, we simply need more research. There are good reasons to expect leaders with more education to be better at their jobs, and there are also good reasons to be

both GDP growth and educational attainment in the United States following World War II. An International Monetary Fund (IMF) report (Arezki et al. 2012) notes correlations between the educational attainment of senior economic policymakers and several measures of government outputs-but finds a negligible relationship between education and corruption and does not control for other factors that might confound the correlation between education and government performance.

4. However, leaders' occupational backgrounds seem to play an important role in shaping their attitudes and choices (Carnes 2012, 2013; Carnes and Lupu 2015). skeptical. Are politicians with more formal education really better leaders?

\section{DATA}

If educated people make better politicians, we should be able to observe differences in a variety of outcomes that occur under their stewardship. Previous studies have focused primarily on economic growth. But citizens expect more from government than just GDP gains. In this article, we focus on a far broader set of economic outcomes: growth but also inequality, unrest, unemployment, and inflation. And we focus on several noneconomic outcomes that citizens care about: interstate conflict, reelection, productivity, and corruption.

Of course, if we were to simply study the relationship between a given outcome variable and the education level of a political leader, we would risk uncovering endogenous correlations. People run for office strategically, when they think the time is right. They leave office strategically, too (e.g., Jacobson 1989). If people with more education make these kinds of decisions differently-if they are less likely to run when the economy is weak, crime is high, the government is unpopular, and so forth (perhaps because people with more education can pursue other lines of work when politics is a less attractive job) - any observed link between education and leader performance might reflect strategic entry and exit, not the popular idea that educated leaders are better at governing.

We cannot completely resolve these inferential problems, that is, we cannot randomly assign governments to be run by more and less-educated people. But in the last few years, scholars interested in the effects of leaders have attempted to address one important source of endogeneity, strategic entry and exit, by analyzing leaders who took office somewhat unexpectedly through arbitrary transitions or extremely narrow elections-in other words, through as-if random assignment (Dunning 2012; Jones and Olken 2005). As Besley et al. $(2011,209)$ note, it "is important ... that the timing of ... leadership transitions is unrelated to underlying economic and political conditions," and one useful strategy is to focus on leaders "who left office because of natural death, accident, or serious illness, such as a stroke."

Studying leaders who take office unexpectedly does not allow scholars to identify the true causal effect of education on leader quality. When a leader dies unexpectedly, for instance, the level of education of her successor is not randomly assigned. However, studying unexpected leadership transitions helps guard against one important potential source of endogeneity: that educated people might be more likely to go into politics when political outcomes are good and more likely to leave politics for the labor market when times 
are tough politically. Because politicians enter and leave office strategically, it is not enough to simply study the association between education and leader quality. Studying unexpected leadership transitions does not identify the causal effect of education without additional assumptions, ${ }^{5}$ but it helps to ensure that we are not mistaking educated politicians jumping ship when times are tough for educated people being better politicians.

In this article, we analyze three data sets. Following Besley et al. (2011), we first examine the effect of as-if random leadership transitions across countries. We ask what happens when a leader leaves office unexpectedly due to illness or death (and not for other reasons like retirement, term limits, electoral defeat, or coups) and disaggregate the data by whether the leader who takes over has a college degree or not. ${ }^{6}$ Like these previous authors, we examine how GDP changes, but we also analyze several other important markers of national prosperity: unemployment, inflation, economic inequality, the frequency of major strikes, and deaths from interstate conflicts. If more educated politicians really are better leaders in a broad sense, when a collegeeducated leader takes office unexpectedly, the country should thrive in more ways than simply increasing its GDP.

And if more educated leaders really are better leaders, when they take office somewhat unexpectedly, they should tend to be more effective and should tend to stay in office longer. To test these possibilities, we analyze data on the US Congress, an institution where we can study data on the vote margins of tens of thousands of politicians. We focus in particular on members who won their first elections by extremely narrow margins-members who arguably entered

5. For instance, if we are willing to make the assumption of conditional parallel paths, then analyzing how our outcome variables changed between the five years before and after a random transition (conditioning on relevant factors before the transition) would allow us to estimate the causal effect of education. Appendix table le reports an analysis that restricts the sample in table 1 below to countries that experienced random leadership transition, analyzes changes in three outcome variables between the five years before the transition and the five years after, controls for the level of the outcome variable in the year prior to the transition, and regresses the change in the five-year average before and after the transition on indicators for countries with different combinations of collegeeducated and non-college-educated leaders. (Because this analysis restricts our sample to countries that experienced transitions and for which we have five years of pre- and post-transition outcome data, we only examine three outcome variables, we have far fewer cases, and we have no cases of transitions from a college-educated leader to a non-college-educated leader.) The results are substantively identical to our findings in table 1-college-educated leaders do not perform better.

6. In other words, our research design examines heterogeneous treatment effects by the leader's education level. office as-if at random (Lee 2008). ${ }^{7}$ Among those elected through an as-if random process, did those who had college degrees tend to pass more bills? Were they more likely to win their reelection bids? Did they stay in office longer?

We also analyze data from Brazil on a uniquely reliable measure of corruption. Since 2003, an anticorruption office of the federal government in Brasília has audited the budgets of 250 randomly selected municipalities per year (see Brollo et al. 2013; Ferraz and Finan 2008, 2011). This gives us both a random sample from Brazil's roughly 5,500 municipalities and reliable data on whether independent auditors found evidence of suspicious activity. Do collegeeducated mayors engage in less corruption?

Of course, this approach is far from exhaustive: our analyses of reelection, bill passage, and corruption each focus on just one country in which we have a unique opportunity to reliably study an important outcome. However, these analyses represent the broadest effort to date to measure the relationship between education and leader quality. We study a variety of leaders-executives, legislators, and mayors-and a wide range of outcomes that citizens the world over care about-economic performance, war, reelection, effectiveness, and corruption. If education truly is a marker of leader quality, we should see evidence of it in at least some of our analyses.

\section{LEADER EDUCATION AND PROSPERITY ACROSS COUNTRIES}

Do more educated leaders govern over more prosperous countries? To find out, we replicated Besley et al.'s (2011) analysis of cross-national data on the education levels of national executives. In their work, they collected information about the highest degree earned by each national leader identified in the Archigos data set, which covers roughly 228 countries that existed between 1875 and 2004 (Goemans, Gleditsch, and Chiozza 2009). Besley et al. used the Archigos coding for the reason behind a leadership transition and then assumed (following Jones and Olken 2005) that those cases where the head of state left office unexpectedly due to illness or death by natural causes were asif randomly assigned. They then estimated how the average annual change in logged GDP per capita differed between the five years before the transition and the five years after

7. Eggers et al. (2015) recently found that the assumption that close elections imply as-if random assignment is questionable in the case of the US House of Representative after 1946 (though it appears to be valid prior to that and among Brazilian mayors). Appendix table 2a replicates our analysis using only members of Congress elected prior to 1946. Our results remain substantively consistent. 
and disaggregate that difference by the level of education of the leader before and after the transition.

Our approach differs from theirs in three important ways. First, we analyze a far wider range of outcome variables. We use the GDP per capita data that Besley et al. (2011) examine, ${ }^{8}$ but we also analyze data on several other markers of national well-being: (1) economic inequality-the share of national income going to the top $1 \%$ of earners-computed by Piketty and Saez and their coauthors (Alvaredo et al. 2014), which are available for about half of the countries in the data set beginning in the early twentieth century; (2) strikesmajor work stoppages involving more than 1,000 peoplecompiled by Banks and Wilson (2013) and available for the period 1901-99; ${ }^{9}$ (3) the unemployment and inflation rates, available from the World Development Indicators for the years 1980 to 2010; and (4) interstate conflict-the number of militarized interstate disputes (MIDs) begun each year-from the Correlates of War data set (Kenwick et al. 2013) for the period 1840 to 2010. With these data, we can ask not just whether educated leaders produce growth, but whether they produce national prosperity, broadly defined.

Second, we focus on the difference between leaders with college degrees and leaders without. Besley et al. (2011) measure educational attainment several ways, including a categorical scale as well as simple indicators for leaders who attended college and leaders who attended graduate school. To be consistent with the other analyses in this article-and to make our presentation clearer-we simply use an indicator for college attainment (which produces the same basic results as alternative educational measures).

Third, we use a more parsimonious empirical model. Besley et al. (2011) estimate complex models that incorporate information about the outcome variables and the explanatory variables both before and after the leadership transition. We simply estimate models that relate our economic performance measures after transitions to the education levels of the leaders who take office-we do not include data on the performance of the economy before the transition or the education level of the leader who suddenly left office (although adding those variables does not change our findings; see appendix table $1 \mathrm{~b}$ ). If the transitions were assigned as-if randomly, it should not matter what values the variables took prior to the transition. We should be able to estimate the effect of random leadership transitions with a between-subjects design, that is, by simply studying how post-

8. The GDP per capita data come from the Maddison Project (Bolt and van Zanden 2013).

9. We also estimated models using a composite measure of unrest that summed the number of strikes, riots, and major demonstrations from the Banks data set (see appendix table 1a). treatment outcomes differed between treated country-yearsthose in which a random leadership transition took placeand control country-years-those in which it did not. And we should be able to determine whether the effect of random leadership transitions was different when a more educated leader took office and when a less educated leader took office.

Like Besley et al. (2011), we estimate fixed-effects models with country- and year-specific intercepts. We regress our economic outcome measures on either an indicator for countries that experienced an unexpected leadership transition in the last five years (" 5 years after transition") or, separately, on both an indicator for countries that had experienced these transitions in the last five years and that had college-educated leaders (" 5 years after trans-college") and an indicator for countries that had experienced these transitions and that had leaders without college degrees (" 5 years after trans-no college"). We also report the differences between the coefficients for these two indicators ("The Difference College Makes"), which illustrate how much better countries performed in the years after leaders with college degrees were thrust into office compared to the years after leaders without college degrees took office unexpectedly..$^{10}$ Table 1 reports our findings.

As the first of each pair of columns in table 1 illustrate, countries that experienced random leadership transitions did not, on average, experience seismic quality-of-life changes. During the five years after these transitions, GDP per capita in these countries was about the same, on average, as GDP per capita in other countries, and the numbers of strikes were essentially the same, too. Economic inequality was significantly higher, although not dramatically so-the top $1 \%$ of earners took home just $0.86 \%$ more of the country's income than they did in countries that had not experienced random leadership transitions. Unemployment, inflation, and MIDs were more or less the same as in other states.

On all six measures, countries governed by collegeeducated leaders performed about the same as-or worse than-countries governed by leaders without college degrees. The estimates in the second column in table 1 report the difference in the average GDP per capita between countries that were not within five years of a random leadership transition (the omitted category), those that were within five years of a random transition that had college-educated leaders, and those that were within five years but had leaders without college degrees. It also lists "The Difference College Makes," that is, the expected difference in GDP per capita between post-transition countries with college-educated leaders and post-transition countries without them (in other

10. We also estimated models that used one- and three-year intervals rather than five-year intervals; see tables $1 \mathrm{c}$ and $1 \mathrm{~d}$ in the appendix. 


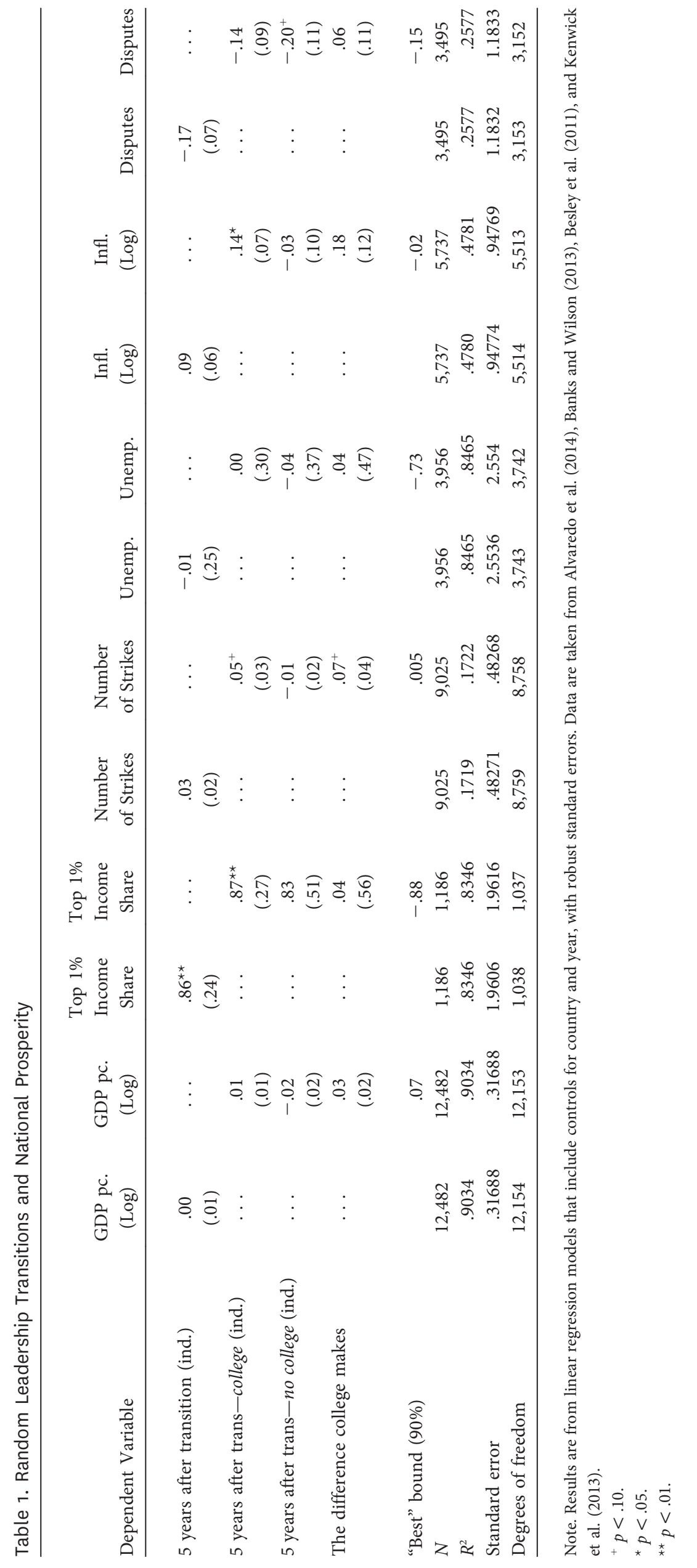


words, the difference in the average treatment effect for each group). As Besley et al. (2011) show, countries governed by educated leaders do slightly better in the years after a random transition-logged GDP per capita is 0.01 higher than in other countries, whereas the logged GDP per capita of countries governed by non-college-educated leaders is 0.02 lower than that of other countries. However, in our analysis, this moderate difference is not statistically significant-Besley et al.'s (2011) finding is not robust to minor changes to the model specification. In post-transition countries, those where college-educated leaders take over have slightly better economic growth rates than those in which non-college-educated leaders take over, but the difference is not significantly distinct from zero. ${ }^{11}$

Of course, a nonsignificant finding like this one could simply reflect a shortage of statistical power. In these instances, one solution is to report the $90 \%$ confidence intervals around the estimate-if all of the values within the $90 \%$ confidence interval are substantively negligible, the researcher can "confidently reject the ... hypothesis of a meaningful effect" (Rainey 2014, 5). Table 1 reports both the difference college makes and the "best" bound around that estimate-the $90 \%$ confidence interval that most favors college-educated leaders (if the outcome is good, like GDP per capita, we report the upper bound of the estimate; if the outcome is bad, like strikes, we report the lower bound). The upper bound of the difference estimate is 7\%: after a random leadership transition, adding a leader with a college degree (relative to adding one without a college degree) means that logged GDP per capita is 0.07 higher-at best. This is a nontrivial difference, so we cannot entirely rule out the possibility of a meaningful effect. But our findings are a far cry from the confident assertions that scholars often make about the virtues of educated leaders. When it comes to economic performance, the data we examine would never be enough to convince a critical reader that educated leaders produce better economies.

The same is true for economic inequality. As the fourth column in table 1 shows, the percentage of income going to the top $1 \%$ of earners was 0.87 points higher when collegeeducated leaders took over after random transitions and 0.83 points higher when leaders without degrees did. If anything, educated leaders seem to make economic inequality slightly worse: the share of income going to the top $1 \%$ was

11. We also used our data on Brazilian mayors (see the following) elected between 2000 and 2008 to ask whether those with college degrees oversaw greater economic growth. Table 3 reports the results of this analysis. Among mayors elected as-if randomly, those with college degrees achieved average annual GDP per capita growth that was 0.005 percentage points higher.
0.04 percentage points higher in post-transition countries with college-educated leaders, compared to post-transition countries with non-college-educated leaders. The $90 \%$ confidence interval around this estimate did not include many values that would make college-educated leaders look substantively appealing: the best bound (the lower bound) was -0.88 . In other words, when we estimate the difference a college degree makes, the $90 \%$ confidence interval around that estimate does not include even a 1 percentage point reduction in the share of income going to the top $1 \%$.

Worse still, as the last column of table 1 illustrates, when college-educated leaders govern in the wake of random leadership transitions, there are significantly more strikes, relative both to countries that do not experience random transitions (the estimate on the indicator " 5 years after trans-college" is significant) and relative to countries that experience random transitions and are governed by people without college degrees (the estimate on "The Difference College Makes" is significant). This may reflect the fact that educated leaders are more likely to be drawn from parties that oppose labor, are more likely to be drawn from management jobs, or are simply less likely to be sympathetic to unions. Whatever the reason, this analysis sharply contrasts the idea that educated politicians tend to be better leaders. Those with college degrees do not seem particularly good for growth or inequality-and they actually seem to promote work stoppages.

Our data on unemployment, inflation, and MIDs paint a similar picture. On all three measures, post-transition countries governed by college educated leaders performed about the same as those governed by leaders without college degrees. Even the generous "best bounds" on all three measures were substantively tiny.

If education is a marker of leader quality, it is not evident in our analysis of these cross-national data. On several quality-of-life indicators, countries suddenly governed by college-educated leaders tended to perform the same as or worse than countries suddenly governed by people without college degrees. Scholars and citizens routinely assume that educated leaders produce better economies and better countries. In reality, whether the national executive has a college degree does not seem to predict how a country will perform.

\section{EDUCATION, EFFECTIVENESS, AND REELECTION IN THE US CONGRESS}

Leaders with more formal education may still produce better outcomes in other domains. They might be better at moving proposals through the legislative process. Or they might be more adept at electoral politics-keeping constituents happy, running campaigns, and winning elections. 
Are they? It can be difficult to know. In most democracies, it is difficult to know how much credit or blame national executives deserve for specific policies. And national executives face strict term limits in many countries, which makes it impossible to study their reelection rates. ${ }^{12}$

One country where we can study a large sample of politicians who can be linked to the passage of specific bills and who can stand for reelection indefinitely is the United States. In the US Congress, hundreds of candidates run for office at regular intervals, they do not face term limits, historians have kept detailed information about their personal backgrounds-including whether they had college degreesand scholars have computed useful measures of their effectiveness as legislators. Moreover, because Congress is so large, it is possible to observe many politicians who were first elected as-if randomly, that is, those who won by narrow margins and whose performance in office is therefore less likely to be affected by strategic entry (although, as before, studying this group helps to guard against one potential source of endogeneity but cannot identify the causal relationship between education and leader quality). Between 1901 and 1996, for instance, the Roster of US Congressional Officeholders data set (ICPSR and McKibbin 1997) includes data on the educational backgrounds and electoral fortunes of 3,954 unique members-including 348 who first won office with between $50 \%$ and $51 \%$ of the popular vote, a group that we can think of as holding office essentially at random. ${ }^{13}$

Did those with college degrees pass more legislation? Did they stay in office longer? Were they less likely to leave office because they lost a bid for reelection? Table 2 reports the results of a simple analysis of how many bills each member of Congress passed, how long each member remained in

12. In our cross-national data, there is no way to measure how effective national executives were at passing legislation, and many of the leaders were either not elected or faced strict term limits.

13. Of those, about $14 \%$ did not have college degrees. Of course, in close elections, it is possible that both parties might anticipate a photo finish and put forward their best candidates (and that there would consequently be fewer differences between the college-educated and non-college-educated among this group than among candidates first elected by larger margins). As a robustness check, we replicated our analysis focusing on legislators who were not first elected in close races. The results-which we report in appendix table $2 \mathrm{~b}-$ are strikingly similar. We also estimated models using data on members elected in close races that regressed each outcome on additional controls for factors that might influence the member's education level (gender, party, state of birth, and military service). If we assume simple conditional independence, these associations can be considered estimates of the effects of education on leader performance. They too are unremarkable (see appendix table $2 \mathrm{c}$ ): one metric was positively and significantly associated with having a college degree-number of bills introduced-but the effect was substantively miniscule and only evident in one out of the nine auxiliary models we estimated (roughly what we would expect by chance alone).
Congress, and whether each member left because he or she lost a bid for reelection. ${ }^{14}$

As in table 1, the first column in table 2 reports a regression model that relates the number of bills each member passed in a typical congressional term (averaged across the member's entire career) to an indicator for whether that member entered office as-if randomly, that is, an indicator for members who first won office with less than 51\% of the popular vote. The second column reports a model that examines how narrowly elected members who had college degrees differed from narrowly elected members who did not have college degrees. We also include state and year fixed effects (separate intercepts for all 50 states, the year the member first took office, and the year the member left office) and an indicator for whether the member served in the House or the Senate. The third and fourth columns report the results of two identical models that analyze the number of years each member ultimately served in Congress. The fifth and sixth columns analyze models that use an indicator for whether each member ultimately left office by losing a reelection bid.

The estimates in table 2 paint an unremarkable picture. In sharp contrast to the idea that educated leaders are better leaders, we again find that politicians with college degrees perform about the same as politicians without college degrees. As the first column illustrates, members who were narrowly elected the first time passed almost exactly as many bills in a typical year as members elected by more comfortable margins. Those with and without college degrees were almost identical in their legislative effectiveness.

Likewise for the third and fourth models in table 2. Members first elected by small margins tend not to stay in office as long-they served an average of 0.22 fewer years. However, more and less educated members were essentially the same in this respect-a narrowly-elected member with a college degree served just 0.09 more years than a narrowly-elected member without a degree, a gap that is not statistically significant. The "best" bound on the estimate is small as well; the largest value within the $90 \%$ confidence interval around our estimate of the benefit of having a college degree is just 0.37 years, about one fifth of a House term and one sixteenth of a Senate term.

As the fifth and sixth models illustrate, members with college degrees who won narrowly the first time were al-

14. Of course, members facing the prospect of losing might strategically opt to retire rather than face defeat at the polls. This analysis focuses on whether members who ran for reelection lost, that is, whether members were both unpopular and nonstrategic, a useful measure of a member's skills in the arena of electoral politics. 
44 / Education and Leader Quality Reconsidered Nicholas Carnes and Noam Lupu

Table 2. Education and Legislator Performance in the US Congress

\begin{tabular}{|c|c|c|c|c|c|c|}
\hline Dependent Variable & $\begin{array}{l}\text { Bills } \\
\text { Enacted }\end{array}$ & $\begin{array}{c}\text { Bills } \\
\text { Enacted }\end{array}$ & $\begin{array}{l}\text { Years in } \\
\text { Congress }\end{array}$ & $\begin{array}{l}\text { Years in } \\
\text { Congress }\end{array}$ & $\begin{array}{c}\text { Lost } \\
\text { Reelection } \\
\text { Bid (Ind.) }\end{array}$ & $\begin{array}{c}\text { Lost } \\
\text { Reelection } \\
\text { Bid (Ind.) }\end{array}$ \\
\hline Member first elected in close race (ind.) & $\begin{array}{l}.00 \\
(.01)\end{array}$ & $\ldots$ & $\begin{array}{c}-.22^{\star *} \\
(.07)\end{array}$ & $\ldots$ & $\begin{array}{l}.09^{* *} \\
(.02)\end{array}$ & $\ldots$ \\
\hline $\begin{array}{l}\text { Member first elected in close race-college } \\
\text { (ind.) }\end{array}$ & $\ldots$ & $\begin{array}{c}.01 \\
(.01)\end{array}$ & $\ldots$ & $\begin{array}{r}-.20^{*} \\
(.08)\end{array}$ & $\ldots$ & $\begin{array}{l}.08^{* *} \\
(.02)\end{array}$ \\
\hline $\begin{array}{l}\text { Member first elected in close race-no college } \\
\text { (ind.) }\end{array}$ & $\ldots$ & $\begin{array}{c}.00 \\
(.01)\end{array}$ & $\ldots$ & $\begin{array}{r}-.30^{*} \\
(.15)\end{array}$ & $\ldots$ & $\begin{array}{l}.10^{* *} \\
(.04)\end{array}$ \\
\hline The difference college makes & $\ldots$ & $\begin{array}{l}.01 \\
(.01)\end{array}$ & $\ldots$ & $\begin{array}{c}.09 \\
(.16)\end{array}$ & $\ldots$ & $\begin{array}{r}-.02 \\
(.04)\end{array}$ \\
\hline "Best" bound (90\%) & $\ldots$ & .02 & $\ldots$ & .37 & $\ldots$ & -.07 \\
\hline$N$ & 3,555 & 3,555 & 3,555 & 3,555 & 3,555 & 3,555 \\
\hline$R^{2}$ & .4325 & .4326 & .9598 & .9598 & .2355 & .2356 \\
\hline Standard error & .16829 & .1683 & 1.7249 & 1.7251 & .45205 & .45211 \\
\hline Degrees of freedom & 3,318 & 3,317 & 3,318 & 3,317 & 3,318 & 3,317 \\
\hline
\end{tabular}

Note. Results are from linear regression models estimated with robust standard errors and controls for state, chamber, the year the member first took office, and the year the member left office. Data are from members who first served in Congress between 1901 and 1996; data are taken from ICPSR and McKibben (1997).

${ }^{*} p<.05$.

${ }^{* *} p<.01$.

most exactly as likely to eventually leave office by losing reelections, and the best value in the $90 \%$ confidence interval around that estimate was -0.07 , a tiny seven percentagepoint gap. If educated leaders are better, it is not at all apparent in data on the legislative effectiveness or electoral fortunes of members of the US Congress. ${ }^{15}$

Although scholars and political observers routinely assume that educated leaders are better politicians, members of Congress with college degrees do not tend to stay in office longer, pass more bills, or win reelection more often. If anything, college-educated members of Congress seem to perform slightly worse at the polls. If college is a marker of leader quality, it is not evident when voters cast their ballots for members of Congress.

\section{CORRUPTION IN BRAZIL}

Educated leaders do not seem to have big advantages when it comes to highly visible outcomes like economic perfor-

15. We also used our data on Brazilian mayors (see below) elected between 2000 and 2012 to ask whether those with college degrees were more likely to be reelected. The last two columns in table 3 report the results of this analysis. Among mayors elected as-if randomly, those with college degrees were just 5 percentage points more likely to be reelected in the next election. mance and reelection. But what about what happens behind closed doors? Do more educated leaders oversee cleaner, less corrupt governments?

Studying outcomes that usually remain hidden has important methodological advantages. If educated people are more likely to go into government in places where government is already performing well, we might wrongly conclude that educated leaders cause government to perform well. We can reduce the risk of this sort of selection bias, however, by studying outcomes like corruption that are normally hidden from public view. If people do not know whether the government is performing well on a given outcome before they take office-and if they do not expect anyone to ever observe the outcome on their watch-we can be more confident that any differences we see between more and less educated politicians reflect differences in their quality, not simply educated people choosing to run when government is already performing well.

Of course, measuring corruption is notoriously thorny, for the obvious reason that most corruption is hidden from the public eye (see Treisman 2007). Fortunately, uniquely reliable data on corruption are available for a random sample of municipal administrations in Brazil.

Since 2003, the federal government of Brazil has tasked an independent agency with selecting municipalities by lottery and auditing their financial records. Within months 
of the audit, the agency posts a report to its website that is also distributed to every level of government. The report contains a list of the irregularities found, including fraud, uncompetitive bidding procedures in procurement contracts, over-invoicing, diversion of funds, lack of completeness, nonutilization of funds, and undocumented expenses. Between 2003 and 2008, over 1,500 of Brazil's municipalities were audited, providing us with a sizeable random sample.

All of the audited funds fall under the purview of the municipal executive, the mayor. City councils in Brazil are not involved in the management of municipal funds, though they are expected to serve an oversight capacity. Since mayoral candidates in Brazil must report their level of education when they register, we can examine whether more educated mayors are less likely to engage in corrupt practices than their less educated counterparts.

Brollo et al. (2013) classify the irregularities reported by the auditors into a broad definition of corruption, including irregularities that could be interpreted as poor management rather than corruption per se, and a narrow definition that includes only severe irregularities. ${ }^{16}$ To determine whether municipalities with educated mayors performed better, we examined both these binary measures of whether an audit uncovered corruption-either broadly or narrowly definedand data on the proportion of the total audited funds that were involved in each type of corruption.

Table 3 reports the results of linear models that regressed these measures of corruption on indicators for mayors elected in close races (defined here as elections in which the winner's margin of victory was less than five percentage points) and, separately, on indicators for mayors elected narrowly who held college degrees and those who did not. ${ }^{17}$ (Again, this approach

16. As the authors note, broad corruption includes "(i) 'illegal procurement practices,' occurring when any of these episodes are reported: (a) competition has been limited, e.g., when associates of the mayor's family or friends receive nonpublic information related to the value of the project, $(b)$ manipulation of the bid value, $(c)$ an irregular firm wins the bid process, $(d)$ the minimum number of bids is not attained, or $(e)$ the required procurement procedure is not executed; (ii) 'fraud'; (iii) 'favoritism' in the good receipt; (iv) 'over-invoicing,' occurring when there is evidence that public goods or services are purchased for a value above the market price; (v) 'diversion of funds'; and (vi) 'paid but not proven,' occurring when expenses are not proven (Brollo et al. 2013, 1775). Narrow corruption includes '(i) severe illegal procurement practices; (ii) fraud; (iii) favoritism; and (iv) over-invoicing' (ibid).”

17. Of the audited municipalities, $36 \%$ had a mayor who attended college. We use linear models even with the binary broad/narrow corruption variables for ease of interpretation, but note that logistic regressions yield similar results (see appendix table 3a). As a robustness check, we estimated models that added additional controls for factors that might influence a mayor's education level (gender, age, and party affiliation). The results (reported in appendix table 3b) were generally consistent, although broad and narrow corruption as a percentage of government spending was significantly negatively associated with helps to avoid confusing strategic entry by college-educated politicians with educated politicians performing better, although it is by no means a causal identification silver bullet.) We again included fixed effects for the available data on time and place (region indicators and indicators for whether the audit took place during the $2001-5$ or $2005-9$ terms). ${ }^{18}$ We also clustered the standard errors by municipality since some municipalities were randomly selected for auditing more than once.

As table 3 illustrates, on average, narrowly elected mayors were no more likely to engage in corruption than other Brazilian mayors. And of those, college-educated mayors were no less likely to engage in any measurable form of corruption. Even the "best" bound around the estimated difference that college makes was tiny-it suggested that collegeeducated mayors were 1 percentage point more likely to engage in broad corruption, 10 percentage points less likely to engage in narrow corruption, and that approximately $1.89 \%$ and $1.11 \%$ of their cities' budgets were spent on broad and narrow corruption, respectively. If anything, college-educated mayors were slightly more likely to engage in broad corruption. Within the $90 \%$ confidence intervals, mayors with college degrees were at best trivially less corrupt than mayors without college degrees.

Using the best available data on executive-level corruption, there seems to be no reason to think that more educated leaders engage in less corruption. Although scholars routinely assume that educated leaders are better, we simply cannot find much evidence for this assumption in hard data.

\section{WHAT GOOD IS A COLLEGE DEGREE?}

In the foreword to The Best and the Brightest-Halberstam's ([1972] 2002, xi) classic account of the choices that plunged the United States into the Vietnam War-Senator John McCain reflects on the links between educational credentials and political leadership: "The men who sent Americans to war in Vietnam were, by many standards, the best and the brightest. They were extraordinarily intelligent, welleducated, informed, experienced, patriotic, and capable leaders.... But in the end, they had more confidence than vision, and that failing bred in them a fateful hubris."

having a college degree. The associations were substantively small, however, were not more than we would expect to observe by chance after estimating so many primary and auxiliary regression models, and were still far short of the kind of evidence it would take to justify the sweeping assumption that educated leaders perform better.

18. We also estimated models that controlled for municipal population, literacy, urbanization, and per capita income (see appendix table $3 \mathrm{c}$ ). All of these models yielded similar results. 


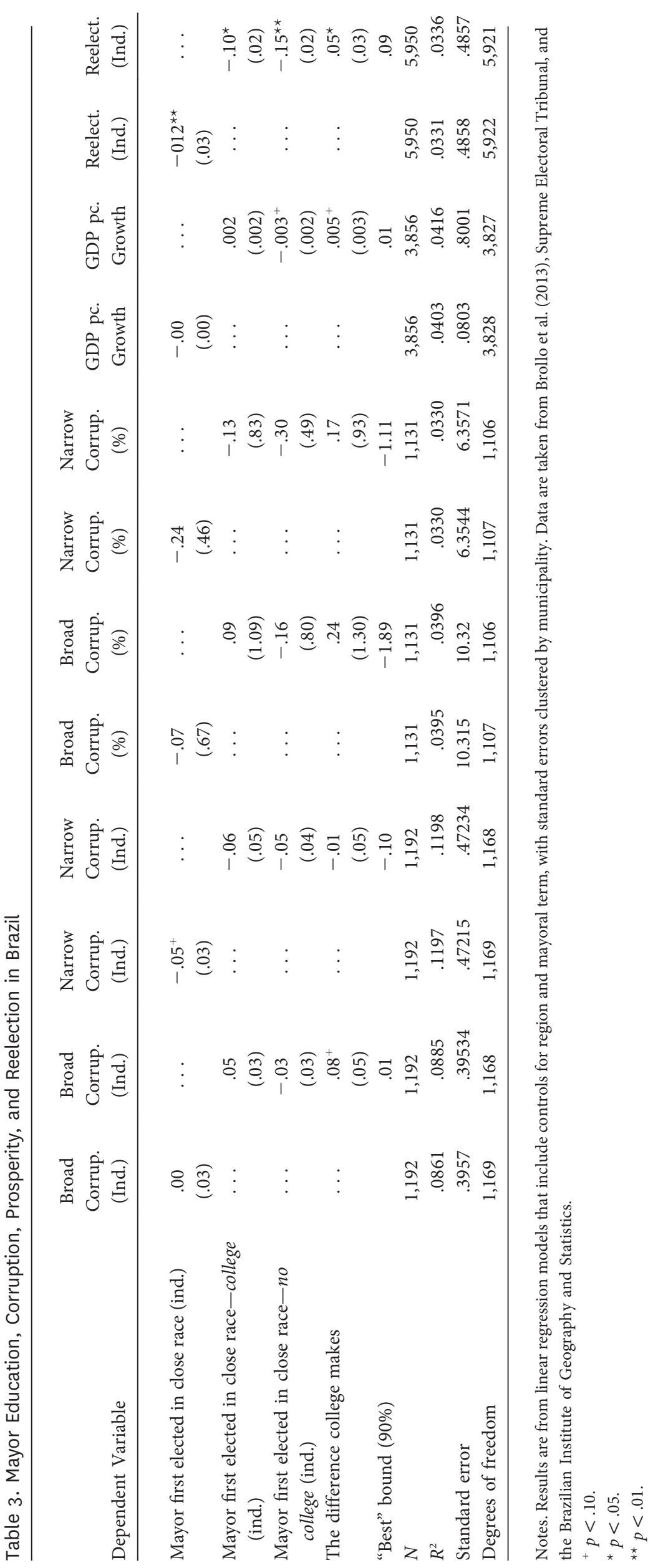


Although scholars and political observers often assume that education is a marker of leader quality, even leaders with heaps of educational credentials can plunge countries into disastrous military conflicts, embark on ruinous economic agendas, and inflict misfortunes of virtually any kind on the people they govern.

But are more educated leaders at least better on average? Can scholars use education as a rough proxy for leader quality in empirical analyses? Should citizens prefer candidates with more formal education to those with less, all else equal?

The findings in this article suggest that the answer is "not really." We examined the links between education and the broadest collection of outcomes ever studied, and we consistently found negligible differences between leaders with college degrees and leaders without them. When a national leader takes office unexpectedly, the country does not seem to perform better if the leader has a college degree-it is no less likely to engage in interstate conflicts, its economic output and growth are about the same, and the country may actually experience slightly more labor conflicts. When a candidate wins a close election for the US Congress, the member is not more likely to succeed in future elections if she has a college degree-if anything, her time in office may be slightly shorter. And when a municipal government is audited in Brazil, the auditors are no less likely to find evidence of corruption if the mayor has a college degree. The idea that education is a marker of leader quality is far from the empirical regularity it is made out to be. ${ }^{19}$ People with college degrees may not have more of the skills that make for success in politics, or holding office may be so difficult that only highly skilled people end up in leadership positions (regardless of whether they have college degrees). Across offices that are hard to obtain-like national executives or seats in the US Congress-and in offices that are less competitive-like mayoralties in Brazil-having a college degree does not seem to predict the kinds of outcomes voters look for.

We focused on the broadest collection of outcomes ever studied in connection with leader education-multiple measures of economic performance, reelection, and corruptionbut a great deal more could still be done. Educated leaders tend to perform about as well as other politicians on the measures we examined, but there could always be other

19. Extensive auxiliary analyses (reported in the appendix) reached similar conclusions. In the dozens of robustness checks we conducted, education was associated with positive outcomes in just three modelsabout what we would expect by chance alone-and even then, the associations were substantively tiny. Regardless of how we analyzed the data, our findings were a far cry from the kind of evidence we would need to justify the claim that more educated leaders perform better. measures on which educated leaders perform better. We focused on things that are important to citizens: the economy, war, corruption, and reelection. But future work should examine other outcomes and, for that matter, other countries. ${ }^{20}$ Scholars should continue collecting data and should continue asking whether educated leaders are better than other politicians.

As it stands, however, the burden of proof would seem to rest on those who would argue that education is a marker of leader quality. Political scientists and economists routinely use education as a proxy for leader quality, on the grounds that education is a marker of human capital. But education signifies more than just human capital-including preexisting privileges that have nothing to do with a person's competence or ability-and the human capital associated with education may not transfer easily into political ability. Schooling is an imperfect measure of competence, and general competence alone may not be enough to make someone a good politician. When we examine a wide range of outcomes, we find little evidence of a link between education and leader quality. Our data are by no means exhaustive, but they are the most comprehensive data currently available. If scholars wish to use education as a proxy for leader quality, they need to make a stronger case for doing so. Until then, political scientists should look skeptically at studies that assume that educated leaders are better leaders.

Does this mean that a college education is worthless? Of course not. It would be unreasonable to expect a college degree-or even an advanced degree-to signify anything beyond minimal proficiency in a profession as complex as government. Do we expect recent college graduates to perform brain surgeries? Do we expect students who have just passed the bar exam to design skyscrapers? Of course not-complex jobs require specialized training and heaps of supervised experience. It should come as no surprise that general educational attainment is not a marker of leader quality. It is not a marker of quality in many other complex jobs either.

When citizens evaluate candidates, they probably should not place too much emphasis on their formal educational credentials. Many people without college degrees would make great leaders and many people with walls full of diplomas would make awful leaders. Likewise, scholars should develop other proxies for leader quality. If educational attainment is not a strong predictor of how politicians perform in office, we should search for better markers of quality. There are many promising possibilities: prior experience in public af-

20. We also have not explored the reasons why educated leaders seem to cause more strikes and engage in more corruption, something future studies could take up. 
fairs, or even measures of performance in office like the outcomes we have studied in this article.

One possibility might be to ask whether leaders with degrees in fields related to governing, like political science and public policy, perform better in office. Do politicians with a BA in government perform better than those with a BA in physics? Do leaders with MPAs and MPPs do better than leaders with MDs? The move to study leaders trained in economics is a promising development (e.g., Flores, Lloyd, and Nooruddin 2013; Hallerberg and Wehner 2013; Moessinger 2012; O'Roark and Wood 2011). If we wish to understand the links between education and leader quality, we will need to move beyond the blunt assumption that more schooling is always better and begin asking how exactly education can enhance the performance of the next generation of world leaders.

\section{ACKNOWLEDGMENTS}

For their comments and advice, we thank Hal Brands, Olle Folke, Carlos Gervasoni, Fran Hagopian, Tana Johnson, Chris Johnston, Judith Kelley, Jonathan Renshon, Jessica Weeks, the editor and anonymous reviewers, and seminar participants at ETH-Zurich, Harvard, Oxford, and Vanderbilt. We also thank Tim Besley and Marta Reynal-Querol for sharing their data. José Luis Enríquez provided excellent research assistance. Previous versions of this article were presented at the 2014 meetings of the European Political Science Association and Latin American Studies Association, as well as the FLACSO-ISA Conference.

\section{REFERENCES}

Alvaredo, Facundo, Anthony B. Atkinson, Thomas Piketty, and Emmanuel Saez. 2014. "The World Top Incomes Database." http://topincomes .g-mond.parisschoolofeconomics.eu/ (accessed May 14, 2014).

Arezki, Rabah, Herbert Lui, Marc Quintyn, and Frederik Toscani. 2012. "Education Attainment in Public Administration Around the World: Evidence from a New Data Set.” IMF Working Paper no. 12/231.

Atkinson, Michael M., and Dustin Rogers. 2012. "Better Politicians: If We Pay, Will They Come?" Paper presented at the Annual Meeting of the CPSA, Edmonton.

Bai, Ying, and Titi Zhou. 2014. “'Mao's Last Revolution': A LoyaltyCompetence Tradeoff." Working Paper.

Baltrunaite, Audinga, Piera Bello, Alessandra Casarico, and Paola Profeta. 2012. "Gender Quotas and the Quality of Politicians." CESifo Working Paper no. 3734.

Banks, Arthur S., and Kenneth A. Wilson. 2013. "Cross-National TimeSeries Data Archive." http://www.databanksinternational.com (accessed May 14, 2014).

Bartels, Larry M. 2008. Unequal Democracy. New York: Russell Sage Foundation.

Besley, Timothy, and Marta Reynal-Querol. 2011. "Do Democracies Select More Educated Leaders?” American Political Science Review 105 (3): $552-66$.
Besley, Timothy, Jose G. Montalvo, and Marta Reynal-Querol. 2011. "Do Educated Leaders Matter?” Economic Journal 121 (554): 205-27.

Bolt, Jutta, and Jan Luiten van Zanden. 2013. "The First Update of the Maddison Project; Re-Estimating Growth Before 1820." Maddison Project Working Paper no. 4.

Brollo, Fernanda, Tommaso Nannicini, Roberto Perotti, and Guido Tabellini. 2013. "The Political Resource Curse." American Economic Review 103 (5): 1759-96.

Buckley Noah, Guzel Garifullina, Ora John Reuter, and Alexandra Shubenkova. 2014. "Elections, Appointments, and Human Capital: The Case of Russian Mayors." Demokratizatsiya: The Journal of Post-Soviet Democratization 22 (1): 87-116.

Card, David. 1997. “The Causal Effect of Education on Earnings. In Orley Ashenfelter and David Card, eds., Handbook of Labor Economics. Amsterdam: Elsevier, 1802-63.

Carnes, Nicholas. 2012. "Does the Underrepresentation of the Working Class in Congress Matter?” Legislative Studies Quarterly 37 (1): 5-34.

Carnes, Nicholas. 2013. White-Collar Government. Chicago: University of Chicago Press.

Carnes, Nicholas, and Noam Lupu. 2015. "Rethinking the Comparative Perspective on Class and Representation: Evidence from Latin America." American Journal of Political Science 59 (1): 1-18.

Carnevale, Jessica J., Yoel Inbar, and Jennifer S. Lerner. 2011. "Individual Differences in Need for Cognition and Decision-making Competence among leaders." Personality and Individual Difference 51:274-78.

Clotfelter, Charles T., Helen F. Ladd, and Jacob L. Vigdor. 2007. "How and Why Do Teacher Credentials Matter for Student Achievement?" NBER Working Paper no. 12828.

Congleton, Roger D., and Yongjing Zhang. 2013. "Is It All about Competence?" Constitutional Political Economy 24 (2): 108-24.

De Benedetto, Marco Alberto, and Maria De Paola. 2014. "Candidates' Quality and Electoral Participation: Evidence from Italian Municipal Elections." Unpublished manuscript.

Domhoff, G. William. 1967. Who Rules America? Englewood Cliffs, NJ: Prentice-Hall.

Dunning, Thad. 2012. Natural Experiments in the Social Sciences. Cambridge: Cambridge University Press.

Eggers, Andrew, Anthony Fowler, Jens Hainmueller, Andrew B. Hall, and James M. Snyder Jr. 2015. "On the Validity of the Regression Discontinuity Design for Estimating Electoral Effects: New Evidence from Over 40,000 Close Races." American Journal of Political Science 59 (1): 259-74.

Ferraz, Claudio, and Frederico Finan. 2008. "Exposing Corrupt Politicians." Quarterly Journal of Economics 123 (2): 703-45.

Ferraz, Claudio, and Frederico Finan. 2011. "Electoral Accountability and Corruption: Evidence from the Audits of Local Governments." American Economic Review 101 (4): 1274-311.

Flores, Thomas Edward, Gabriella Lloyd, and Irfan Nooruddin. 2013. "The Technocratic Advantage? Leadership and IMF Programs." Working Paper.

Galasso, Vincenzo, and Tommaso Nannicini. 2011. "Competing on Good Politicians.” American Political Science Review 105 (1): 79-99.

Gilens, Martin. 2012. Affluence and Influence. Princeton, NJ: Princeton University Press.

Goemans, Hein E., Kristian Skrede Gleditsch, and Giacomo Chiozza. 2009. "Introducing Archigos: A Data Set of Political Leaders." Journal of Peace Research 46 (2): 269-83.

Gottesman, Aron A., and Matthew R. Morey. 2006. "Does a Better Education Make for Better Managers?” SSRN Manuscript no. 564443.

Gruber, Wilfried. 1971. "Career Patterns of Mexico's Political Elite." Western Political Quarterly 24 (3): 467-82. 
Halberstam, David. (1972) 2002. The Best and the Brightest. New York: Random House.

Hallerberg, Mark, and Joachim Wehner. 2013. "The Technical Competence of Economic Policy-Makers in Developed Democracies." SSRN Manuscript no. 2191490.

Interuniversity Consortium for Political and Social Research and Carroll McKibbin. 1997. "Roster of United States Congressional Officeholders." Merged data (Study 7803). Ann Arbor, MI: Interuniversity Consortium for Political and Social Research.

Jacobson, Gary C. 1989. "Strategic Politicians and the Dynamics of US House Elections, 1946-86.” American Political Science Review 83 (3): 773-93.

Jones, Benjamin F., and Benjamin A. Olken. 2005. "Do Leaders Matter? National Leadership and Growth since World War II." Quarterly Journal of Economics 120 (3): 835-64.

Kenwick, Michael R., Matthew Lane, Benjamin Ostick, and Glenn Palmer. 2013. Militarized Interstate Dispute Data, Version 4.0.

Kotakorpi, Kaisa, and Panu Poutvaara. 2011. "Pay for Politicians and Candidate Selection: An Empirical Analysis." Journal of Public Economics 95 (8): 877-85.

Lee, David S. 2008. "Randomized Experiments from Non-Random Selection in U.S. House Elections." Journal of Econometrics 142 (2): 675-97. Lippmann, Walter. 1922. Public Opinion. New York: Harcourt Brace.

Lipset, Seymour Martin, and Aldo Solari, eds. 1967. Elites in Latin America. Oxford: Oxford University Press.

Luo, Mi. 2010. "Do Village Elections Select More Competent Leaders? Meritocratic Selection in China's Grassroots Democracy.” Working Paper.
Massey, Douglas S. 2007. Categorically Unequal. New York: Russell Sage Foundation.

Moessinger, Marc-Daniel. 2012. "Do Personal Characteristics of Finance Ministers Affect the Development of Public Debt?" SSRN Manuscript no. 2172748 .

O'Roark, J. Brian, and William C. Wood. 2011. "Determinants of Congressional Minimum Wage Support: The Role of Economic Education." Public Choice 147 (2): 209-25.

Putnam, Robert D. 1976. The Comparative Study of Political Elites. Englewood Cliffs, NJ: Prentice Hall.

Rainey, Carlisle. 2014. “Arguing for a Negligible Effect.” American Journal of Political Science 58 (4): 1083-91.

Steinberg, Jacques. 2009. "No College Degree for One of Every 20 in Congress." New York Times. http://thechoice.blogs.nytimes.com/2009 /12/24/congress/ (accessed May 2, 2014.)

Treisman, Daniel. 2007. "What Have We Learned about the Causes of Corruption from Ten Years of Cross-National Empirical Research?" Annual Review of Political Science 10:211-44.

Verba, Sidney, Kay Lehman Schlozman, and Henry E. Brady. 1995. Voice and Equality: Civic Voluntarism in American Politics. Cambridge, MA: Harvard University Press.

Verner, Joel G. 1974. "Educational Backgrounds of Latin American Legislators: A Three-Country Analysis." Comparative Politics 6 (4): 617-34.

Von der Mehden, Fred R. 1969. Politics of the Developing Nations. 2nd ed. Englewood Cliffs, NJ: Prentice-Hall.

Yu, Shu, and Richard Jong-A-Pin. 2013. "Political Leader Survival: Does Competence Matter?” SSRN Manuscript no. 2359354. 